\title{
How Scientists Obtain Approval to Release Organisms for Classical Biological Control of Invasive Weeds ${ }^{1}$
}

\section{J. Scoles, J. P. Cuda and W. A. Overholt ${ }^{2}$}

An invasive weed is a nonnative plant that exhibits rapid population growth following its arrival in a new environment where it did not evolve. The success of the weed in its new habitat is due in part to the absence of the natural enemies that normally limit its reproduction and spread in its native range.

Classical biological control seeks to reunite an invasive weed with one or more of its co-evolved natural enemies to provide permanent control of the weed.

Classical biological control is defined as the planned introduction and release of undomesticated target-specific organisms (usually arthropods, nematodes or plant pathogens) from the weed's native range to reduce the vigor, reproductive capacity, or density of the target weed in its adventive range. The term "adventive" in this definition acknowledges the fact that the arrival of a weed in a new geographical area can occur by any means (e.g., immigration), and is preferable to the term "introduced," which is restricted to actions taken by people.
Before scientists can release a natural enemy into Florida for biological control of an invasive plant, the potential agent must undergo rigorous testing to ensure that it will not harm other organisms. The candidate agent is exposed to a series of carefully chosen test plants in no-choice and multiple-choice replicated trials in order to demonstrate the natural enemy is safe to release. USDA Animal and Plant Health Inspection Service, Plant Protection Quarantine unit (APHIS PPQ) controls the release approval process. (The Plant Protection Act of 2000 gives APHIS the authority to regulate "any enemy, antagonist or competitor used to control a plant pest or noxious weed.”) A voluntary multi-agency Technical Advisory Group (see first text box), reviews information provided by the requesting scientist prior to making any recommendation to APHIS Plant Protection Quarantine concerning the release of an agent. This interagency group's mission is to advise weed biological control researchers and provide Plant Protection Quarantine permit unit with recommendations on the proposed action.

1. This document is ENY-828, one of a series of the Department of Entomology and Nematology, Florida Cooperative Extension Service, Institute of Food and Agricultural Sciences, University of Florida. Published: May 2005. Please visit the EDIS Website at http://edis.ifas.ufl.edu.

2. J. C. Scoles, writer/editor, Invasive Plant Research Laboratory, USDA/ARS, Fort Lauderdale, FL; J. P. Cuda, associate professor, Entomology and Nematology Department, University of Florida, Gainesville; W. A. Overholt, associate professor, UF-IFAS/DPI-DOACS Biological Control Research and Containment Laboratory, Ft. Pierce.

The Institute of Food and Agricultural Sciences (IFAS) is an Equal Opportunity Institution authorized to provide research, educational information and other services only to individuals and institutions that function with non-discrimination with respect to race, creed, color, religion, age, disability, sex, sexual orientation, marital status, national origin, political opinions or affiliations. U.S. Department of Agriculture, Cooperative Extension Service, University of Florida, IFAS, Florida A. \& M. University Cooperative Extension Program, and Boards of County Commissioners Cooperating. Larry Arrington, Dean 
Before identifying a candidate biological control agent, scientists ordinarily submit a proposed host specificity test plant list to Technical Advisory Group. At this early stage of the approval process, Technical Advisory Group will make recommendations on the target weed choice and comment on the proposed test plant list.

To import a potential weed biological control organism into the United States for host specificity testing, scientists must submit a permit application to APHIS PPQ. It takes 4 to 6 weeks from submission of the application to receive a permit. Approved biological control agents must go into an adequate high-security containment facility upon entry into the United States. The state of Florida currently has three quarantine facilities specifically designed and constructed for this purpose (See http://edis.ifas.ufl.edu/IN509).

In addition to submitting a Technical Advisory Group petition, scientists contact the Department of the Interior to ensure that they consider threatened and endangered species in their test plant list. Receiving input from the Technical Advisory Group and Department of the Interior on a weed biological control project at the beginning of the project will disclose any problems or concerns that the scientists can address at an early stage, potentially saving years of delays.

Release of non-indigenous weed biological control organisms also requires compliance with the Endangered Species Act (ESA), and National Environmental Policy Act (NEPA) (see second text box).

The document required for NEPA compliance is the Environmental Assessment. The Environmental Assessment is a concise public document that provides sufficient evidence and analysis for APHIS PPQ to determine if it can arrive at a finding of no significant impact (a FONSI), or if the submitting scientist must prepare an environmental impact statement. The Environmental Assessment provides the public with the potential positive and negative environmental impacts that might occur as a result of the release of a biological control agent into the environment.
The document required for compliance with the ESA is the Biological Assessment. This document is submitted to the US Fish and Wildlife Service for review. The Biological Assessment typically includes several elements:

- A description of the action under consideration;

- A description of the specific area that the action might affect;

- A description of any listed species or critical habitat that the action might affect;

- A description of the manner in which the action might affect any listed species or critical habitat and an analysis of any cumulative effects;

- Relevant reports, including any environmental impact statements or environmental assessments;

- Other relevant available information on the action, the affected listed species, or critical habitat.

After completing the host specificity testing, the scientist submits a petition for release of the biological control agent to the Technical Advisory Group for recommendation. Although the Technical Advisory Group usually reviews and recommends all proposed first-time releases of non-indigenous weed biological control agents, the scientist may elect to submit the petition to APHIS Plant Protection Quarantine without Technical Advisory Group recommendation. When the scientist receives a recommendation from the Technical Advisory Group for the release of the biological control agent, he or she submits an application requesting release of that agent to APHIS Plant Protection Quarantine along with the draft Environmental Assessment and Biological Assessment. To expedite the review process, it is important to submit documents that are as close to completion as possible.

The ESA requires that the applicant consult with the US Fish and Wildlife Service. A formal or informal consultation will satisfy this requirement. Although applicants should have been in contact with the US Fish and Wildlife Service from the beginning of the process, APHIS PPQ determines if the 


\section{The Technical Advisory Group for Biological Control Agents of Weeds (TAG)}

The TAG is an independent voluntary committee formed in 1957 to provide advice to weed biological control researchers. Today, the TAG provides a forum for exchange of views, information and advice between researchers conducting host range testing of weed biological control agents and regulatory officials in APHIS PPQ responsible for issuing permits for importation / release. TAG members review test plant lists for weed biological control projects, and review petitions for field release of biological control agents of weeds. More information about the TAG is available at the following Web site: http://www.aphis.usda.gov/ppq/permits/tag/

\section{TAG Membership}

One member from each of the following agencies is represented on the TAG:

USDA, APHIS, National Biological Control Institute

USDA, Agricultural Research Service

USDA, Cooperative State Research, Education, and Extension Service

USDA, Forest Service

USDA, Natural Resources Conservation Service

USDI, Bureau of Land Management

USDI, Bureau of Reclamation

USDI, U.S. Fish and Wildlife Service

USDI, National Park Service

USDI, U.S. Geological Survey

USDI, Bureau of Indian Affairs

US Environmental Protection Agency

DOD, US Army Corps of Engineers

Additional members may include one state or federal government employee from each of the following organizations:

The National Plant Board

The Weed Science Society of America

ARS Biological Control Documentation Center

Other federal agencies expressing interest in participating in the process

Representatives from Canada and Mexico are also invited to attend.

applicant must conduct a formal consultation with the agency at this point in the process.

Once the applicant completes consultation with the US Fish and Wildlife Service, APHIS Plant Protection Quarantine incorporates the response from the US Fish and Wildlife Service into the Environmental Assessment and makes any necessary final changes. The USDA Office of General Counsel reviews the Environmental Assessment to ensure it meets all legal standards. Once the Office of General Counsel approves the Environmental Assessment, APHIS Plant Protection Quarantine publishes a 30-day notice of availability of the Environmental Assessment in the Federal Register to allow the public to comment on the proposed action.
After considering the comments, APHIS Plant Protection Quarantine performs one of the following actions:

- Issues the release permit; or

- Advises the applicant that an environmental impact statement must be prepared; or

- Advises the applicant to discontinue the project.

This entire process (see Figure 1) usually requires many months or even years to complete, but it is just the beginning. Once the weed biological control agent is released, it typically takes several years for the organism to establish and have an effect on the target weed. During this time the scientists continually monitor dispersal and collect data on the efficacy of the biological control agent. 


\section{The National Environmental Policy Act of 1969, as amended}

Title 42, Chapter 55, Section $4331 . .$.

(b) In order to carry out the policy set forth in this Act, it is the continuing responsibility of the Federal Government to use all practicable means, consistent with other essential considerations of national policy, to improve and coordinate Federal plans, functions, programs, and resources to the end that the Nation may -

1. fulfill the responsibilities of each generation as trustee of the environment for succeeding generations;

2. assure for all Americans safe, healthful, productive, and aesthetically and culturally pleasing surroundings;

3. attain the widest range of beneficial uses of the environment without degradation, risk to health or safety, or other undesirable and unintended consequences;

4. preserve important historic, cultural, and natural aspects of our national heritage, and maintain, wherever possible, an environment which supports diversity, and variety of individual choice;

5. achieve a balance between population and resource use which will permit high standards of living and a wide sharing of lifes amenities; and

6. enhance the quality of renewable resources and approach the maximum attainable recycling of depletable resources.

The entire National Environmental Policy Act can be viewed online at

http://www4.law.cornell.edu/uscode/html/uscode42/usc_sup_01_42_10_55.html. 


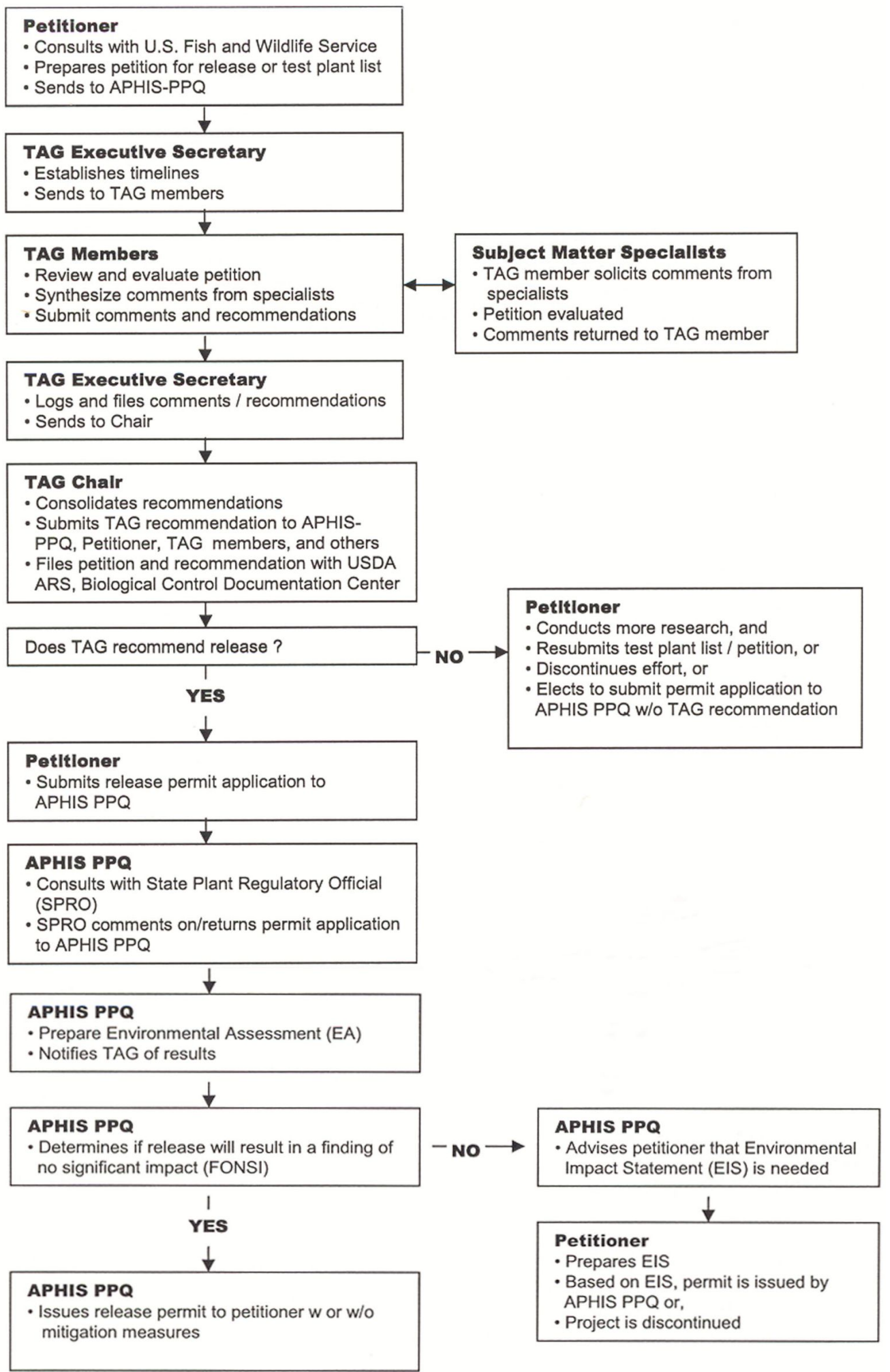

Figure 1. Flow chart illustrating the APIS PPQ permitting process for classical weed biological control agents (Source: http://www.aphis.usda.gov/ppq/permits/tag/flowchart.pdf). 